\title{
JUST SAY NO
}

\section{DR RICHARD I. EVANS EFFORTS TO INFLUENCE JUVENILE BEHAVIOUR THROUGH US PUBLIC HEALTH PROGRAMMING}

\author{
Emily Vinson \\ University of Houston \\ evinson@uh.edu
}

\begin{abstract}
Television as a means of distributing public health information and influencing health behaviours was recognized even in the earliest days of broadcasting, a natural extension of health messaging on radio and film. This paper examines the place health-focused programming held in the United States' educational television landscape and the role of Dr Richard I. Evans, social-psychology researcher, who sought to use television to influence the behaviours of youths engaging in "risky" activities.
\end{abstract}

Keywords: social psychology, juvenile delinquency, public health, educational television, public health, social inoculation theory

\section{Introduction}

Dr Richard I. Evans was a leader in social-psychology research and a pioneer of educational television. He dedicated much of his career to creating television programming and evaluating its ability to change behaviour. Over his sixdecade career at the University of Houston (UH), Evans wrote, appeared in, produced, and studied dozens of television programmes aired on the university-owned station, KUHT. ${ }^{1}$ Two series, namely Target: Delinquency and an untitled series for the Social Psychological Deterrents of Smoking in Schools Project, demonstrated Evans' efforts to use television as a tool to influence health behaviour.

The potential of television as a tool in health education has been recognized since its first appearance. In the United States of America (US), the University of lowa's pioneering television station, W9XK, began to broadcast healthrelated programmes - such as Oral Hygiene and First Aid - as early as the 1930s. ${ }^{2}$ These programmes were a natural extension of the use of film and radio in health education. As the number of US households with a television set grew from $9 \%$ to $90 \%$ between 1950 and $1960,{ }^{3}$ so followed an increase in televised public health programming. Health departments, educational institutions and the US government recognized that they could reach large audiences to inform and affect behaviours on various issues regarding personal and public health. 
Models throughout Europe and indeed much of the world favoured state-supported public service broadcast agencies that offered educational content. By contrast, the US approach to broadcasting, first with radio and later in television, was a patchwork of commercial broadcasters with a few colleges and universities playing the role of on-air educators. This paper explores the unique US approach to broadcasting, which situated television stations within the university setting. The work focuses on psychology professor Dr Evans, who used the freedom provided by a fledgling educational television station to create and test health risk behaviour-prevention programming.

\section{United States Broadcasting and the Quest for Educational Television}

Compared with much of Europe, the US is an outlier in its approach to public service broadcasting. The Public Broadcasting System (PBS), the US equivalent of large public broadcasters such as the British Broadcasting Company (BBC), was not established until 1969. Broadcasters in the US have long been regulated by the government, first under the Radio Act of 1912 and later by the Communications Act of 1934, which established the Federal Communications Commission (FCC). However, the growth and development of stations was often chaotic.

Directed by five commissioners appointed by the President of the US, the FCC is charged with the regulation of US telephone, telegraph, television, and radio communications. In 1939, the FCC designated a reserved band at the lowest end of the FM frequency for non-commercial educational radio stations. These stations were available for educational institutions "for the advancement of its educational work and for the transmission of educational and entertainment programs to the general public". ${ }^{4}$ The FCC began issuing television licenses in 1941. By 1948, 37 television stations had begun broadcasting across the US and another 71 licenses had been issued; however, hundreds of applications awaited approval. The FCC thus issued a temporary freeze on new licenses to allow the commission time to review the applications. Although the freeze was planned to last only a few months, it was not lifted until late 1952. During the "freeze" years, the FCC worked with the broadcast industry to determine frequency allocation and correct signal interferences and to create standards for colour television. ${ }^{5}$ The FCC also held allocation hearings between November 1950 and January 1951 to determine whether frequencies should be reserved for non-commercial educational stations, as was the case in radio.

In the absence of a national "public service" broadcast model, "private foundations, reformers, and educators hoping to rescue television from the ravages of commercial entertainment" 6 rallied for specific frequencies to be allocated to educational television. Up to this point, efforts at educational television had been few and scattered. In 1933, the University of lowa had started to experiment with educational television: silent images were transmitted on W9XK to accompany the programming on the university's educational radio station, WSUI. ${ }^{7}$ By 1948, only five US universities were engaged in educational television, either having applied for licenses or by providing educational programming to commercial stations. ${ }^{8}$ Advocates for educational television wanted to "develop television as an educational technology for cultivating knowledge and cultural excellence". 9 The Joint Committee on Educational Television (JCET) was eventually formed as a consortium of seven constituent organizations that represented "every important segment of American education, at all levels, public and private". ${ }^{10}$ At the 1950-1951 FCC allocation hearings, the JCET presented 75 witnesses to testify in support of its policy as well as hundreds of sworn testimonials in favour of non-profit educational television. Emphasizing the need to reserve broadcast signals for educational purposes, JCET general counsel Telford Taylor noted that only 107 of roughly 500 available channels had been allocated; however, many applicants were competing for the remaining channels. He stated that it was "imperative for the national welfare that the FCC take decisive steps 
now to ensure that there will be at least one television channel for educational use in each large city". ${ }^{11}$ Led by pioneering FCC commissioner Frieda Hennock, ${ }^{12}$ a champion of educational television, in March 1952 the FCC issued an initial ruling that favoured the reservation of non-commercial educational stations. This was followed by the allocation of 242 non-commercial educational stations on 14 April $1952 .{ }^{13}$

One benefactor of the FCC's decision was the UH. Founded in 1927 as a Junior College, the school was reestablished as a four-year university in 1934. A few years later, UH benefited greatly from the financial support of the Texas oil wildcatter Hugh Roy Cullen, who said of his donation, "I have only one condition in making this gift. The University of Houston must always be a college for working men and women and their sons and daughters. If it were another rich man's college, I wouldn't be interested". ${ }^{14}$

The UH bid to embark on educational television was the brainchild of the university's president Walter William Kemmerer. He believed in television's potential to democratize education and viewed television as a natural extension of the school's educational radio station, KUHF. On 1 April 1951, Kemmerer attended a meeting of the JCET at Pennsylvania State College, where one of educational television's most prominent advocates, university president $\mathrm{Dr}$ Milton Eisenhower, spoke of the possibilities that television offered. So convinced was Kemmerer that he proposed a university-operated television station to the university's Board of Regents, explaining that "television was expected to be the greatest educational media of all time". ${ }^{15}$ On 17 April 1951, the UH Board of Regents voted unanimously to apply for a licence from the FCC.

The FCC approved the educational non-profit station designation. Thereafter, UH was assigned Houston's Channel 8 frequency and began broadcasting under the call signal KUHT-TV on 25 May 1953. It was the first non-commercial educational television station to go on air in the US. ${ }^{16}$ At the station's dedication ceremony two weeks later, FCC Commissioner Frieda Hennock described the educational possibilities of television as follows:

With TV, the walls of the classroom disappear, every set within viewing range of the signal is a potential classroom. With it, the finest teachers, doctors and artists may be brought right into the school or home ... In fact, the sky of man's constructive imagination is literally the only limit on the good that can be derived from educational television. ${ }^{17}$

\section{DrRichard I. Evans}

A pioneer of instructional programming at KUHT was psychology professor Dr Richard I. Evans. Born on 29 August 1922 in Chicago, Illinois, Evans was a decorated World War II veteran who completed his PhD in psychology at Michigan State University in 1950. His dissertation was titled "Personal values as factors in antiSemitism." ${ }^{18}$ The work demonstrated his focus on social psychology and behavioural studies, which would become a hallmark of his career.

Evans joined the UH psychology faculty in 1950. In the summer of 1953, he taught the university's first for-credit telecourse, Psychology 231, which aired for half an hour from Monday through Friday. The course lasted 12 weeks and reached an estimated 20,000 viewers. ${ }^{19,20}$ This series was the first psychology course taught via television in the US and was Evans' first project to make the study of psychology accessible to a wide range of students. In the years that followed, Evans' output expanded to include various social science programmes. The weekly series Propaganda and You (1955) was meant to educate and influence the public and stimulate discussion on a range of topics, such as propaganda (as the title suggests). 


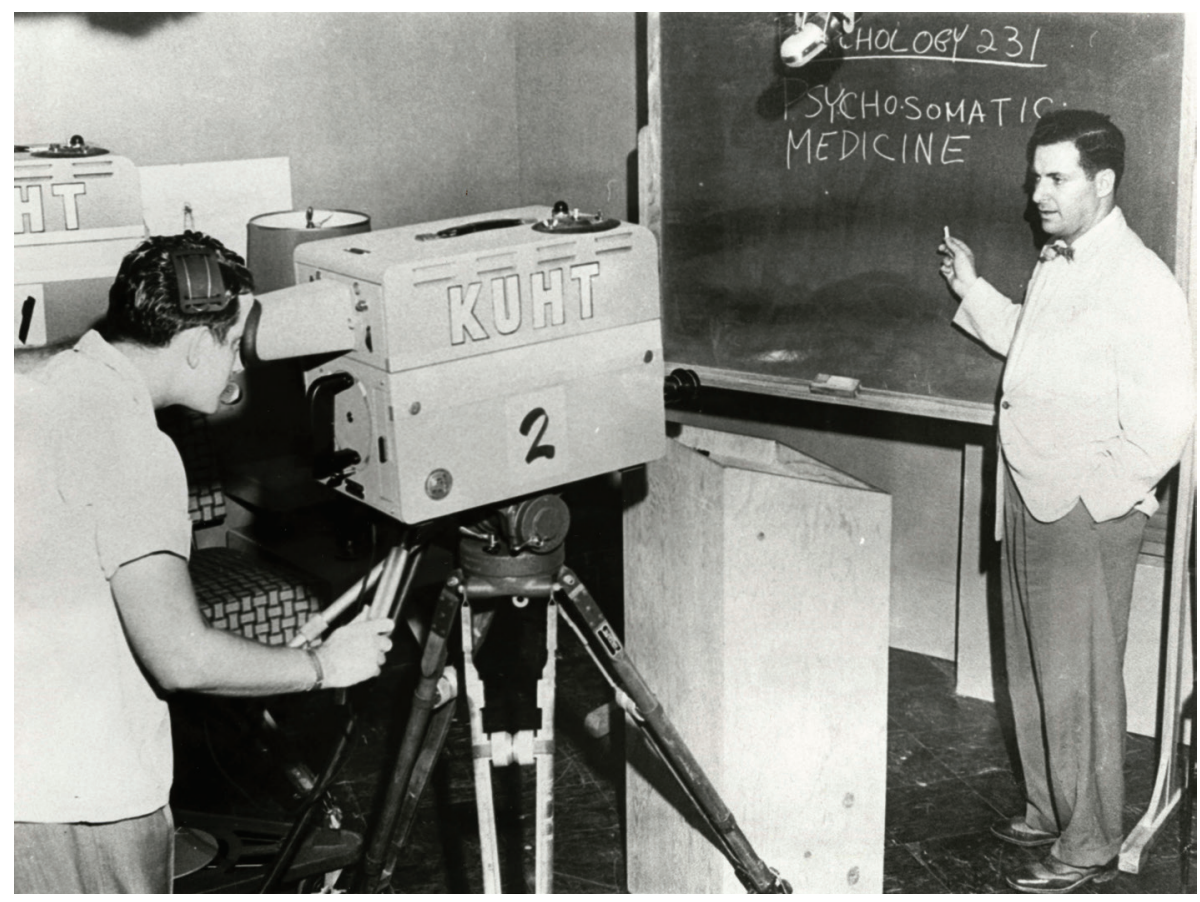

Figure 1. Dr Richard I. Evans lecturing on psychosomatic medicine during his telecourse, Psychology 231 on 8 June 1953. (KUHT Collection, courtesy of University of Houston, Special Collections).

Throughout much of Evans' career, he focused on television as both a teaching tool and a topic for academic research. William Hawes, author of Public Television, America's First Station, noted that "virtually everything Evans did on television, he tested, documented, and reported". ${ }^{21}$ This was evident even in the early years of Evans' work in tele-education. Within a few years of the first KUHT broadcast, he had written extensively on the effectiveness of television instruction regarding for-credit courses. He also wrote about the attitudes of students towards this new mode of education and the educational value of social psychology programming for general audiences. In addition, he produced a monograph analysing the "demographic and psychological characteristics of an educational television audience". 22

Between 1953 and the 1970s, Evans appeared frequently on KUHT and became widely known in the field of educational television. He is best remembered for two interview series, Approaches to the Psychology of Personality (1957) and Notable Contributors to the Psychology of Personality (1963-1969). Supported by substantial grant funding, each episode featured an interview with renowned specialists, including Carl Jung, Burrhus Frederic Skinner, Jean Piaget, Konrad Lorenz, and Erik Erikson. Later, Evans explored the psychology of creativity in interviews with guests such as playwright Arthur Miller and comedians Joan Rivers and Buddy Hackett as well as psychologists $(A$ Psychology of Creativity, 1972). The high-profile interview-based programmes were intended to engage students and create an audio-visual record of experts explaining their best-known contributions to the field. These series were distributed nationally and were reviewed in academic journals; they were also aired by educational stations for viewing by the general public. Additionally, Evans wrote - and published - extensively on all aspects of these series, from the production process to evaluations of their impact. He examined their impact both in classroom settings and regarding their broadcast to general audiences. ${ }^{23}$

Evans also gained a certain celebrity status and often appeared on the late-night entertainment programme The Tonight Show with Johnny Carson. In making these appearances, Evans hoped to "communicate to the public some understanding of psychology as a scientific discipline." He endeavoured to introduce psychological concepts through his conversations with other celebrity guests, including Li'l Abner cartoonist Al Capp, comedic actress Selma Diamond, and Zsa Zsa Gabor. ${ }^{24}$ 
While active in these projects, Dr Evans began to expand his social psychology research to health psychology. Over the course of twenty years, he developed programmes and tested the effectiveness of television meant to inform and influence the health behaviours of audiences.

\section{Television and Public Health}

The US government and local and national health organizations had years of experience utilizing radio and motion picture to distribute public health messages. ${ }^{25}$ An early example was a series of six films released between 1910 and 1915, often referred to as the "Red Seal" films, for which the National Association for the Study and Prevention of Tuberculosis (NASPT) partnered with the Edison Company. ${ }^{26}$ The aim was to convey public health messaging through appealing and entertaining narratives. According to reports in the NASPT publication, Journal of the Outdoor Life, the films traversed the country, playing to huge audiences. In 1912, as the third film in the series (Hope-A Red Cross Seal Story, 1912) was set for release, the NASPT claimed that "possibly no less than ten million people will see the motion picture". ${ }^{27}$

Health campaigners were quick to adopt television as an efficient medium for their messages. In 1953, the Baltimore Health Department noted that television was "commonly used by American health departments, medical societies and other health agencies... to bring carefully prepared health information directly into the homes of millions of persons". ${ }^{28}$ However, Bette Kill and Linda Sue King cautioned in a 1983 article "Historical Trends in the Use of Television in Health Education" that the outcomes of these initiatives were poorly evaluated. According to Kill and King, "there was a lack of clear evaluation criteria, a lack of funds, and problems in controlling extraneous variables". ${ }^{29}$

In Baltimore, Your Family Doctor (1948-1974?) first aired in 1948 on the commercial station WMAR-TV with the objective to promote "better health and attitudes". ${ }^{30}$ An extension of the Baltimore City Health Department's radio show, which began broadcasting in 1932, the weekly 15-minute television programme was produced for at least 25 years. Written by WMAR staff members in consultation with medical professionals, Your Family Doctor utilized varied formats, including dramatizations, panels, and interviews moderated by a fictional doctor. ${ }^{31}$ Over hundreds of episodes, the series covered topics as varied as lead poisoning, mental health, smallpox vaccinations, and civil defence.

Closed-circuit television provided another avenue for targeted health education. In the late 1950s, the School of Nursing at the University of California in Los Angeles sought to make the most of its crowded waiting rooms. Each captive audience was estimated to be "50-75 persons" awaiting prenatal, well baby, and paediatric health appointments. Students in the nursing programme were encouraged to produce short films of relevance to "young" mothers to be aired on closed-circuit television. ${ }^{32}$ In 1955, the community-sponsored educational station of Pittsburgh, Pennsylvania - called WQED - broadcast At Home With Your Child (1955). This 13-episode half-hour programme "attempted to describe and demonstrate how normal babies and children look and act at each stage of development". ${ }^{33}$ Generally, these programmes relied on the familiar format of an authority figure, either a doctor or a nurse, instructing a "patient" regarding best practices for healthy behaviours. The authority figure might also warn the viewer of specific risks they could encounter.

\section{Public Health and Juvenile Delinquency}

As the US entered the 1960s, anxieties around juvenile delinquency came to the fore. The unemployment rate was high, at $6 \%$, and was even higher for urban youths; the high-school dropout rate was over $27 \%$. $^{34}$ These factors, coupled with 
changing assumptions about the causes of juvenile delinquency and concern over crime statistics, led the newly elected administration of President John F. Kennedy to focus on the issue at national level. Within a few months of taking office, Kennedy established the President's Committee on Juvenile Delinquency and Youth Crime to "search in depth for the most creative and imaginative approaches to the control of juvenile delinquency". ${ }^{35}$ The creation of this committee reflected the belief that "poverty and historically structured racial inequalities [were] at the root of escalating crime in America". ${ }^{36}$ This belief was held by President Kennedy - and perhaps even more by Attorney General Robert F. Kennedy.

The above belief was informed by emerging theories of that era. A significant influence was "opportunity theory" proposed by sociologists Richard A. Cloward and Lloyd E. Ohlin in 1960. They argued that juvenile delinquency was the result of being raised in poverty, which led "adolescents in disorganized urban areas who are oriented toward achieving higher positions but are cut off from institutionalized channels" to "seize upon the manipulation of violence as a route to status". ${ }^{37}$ The committee's stance was also influenced by the work of Mobilization For Youth based in New York City's Lower East Side, which "provide[d] education, counselling, job training, placement and support" to combat delinquency. ${ }^{38}$

On 22 September 1961, President Kennedy signed an executive order establishing the Juvenile Delinquency and Youth Offenses Control Act. This was the first Act in US history related to juveniles and the criminal justice system to pass both houses of Congress. ${ }^{39}$ The law authorized $\$ 30$ million in grants over three years to establish pilot programmes to combat the problem. Ten cities were initially selected as grant sites, with Houston being the only Southern city. The grants were administered by the Secretary of Health, Education and Welfare. Their aim was to bring together a city's disparate social service agencies - schools, police, and welfare agencies - to pilot proposed social interventions in a specific area.

Houston's anti-delinquency grant proposal was put forward by UH, which had established the Greater Houston Action for Youth (GHAY) under the direction of Dr Evans. Influenced by Evans' work in television, GHAY departed from other grant recipients in its approach to combating juvenile delinquency. While other recipients generally followed the direct intervention model established by New York City's Mobilization for Youth, GHAY spent a substantial portion of their grant on a media campaign. The centrepiece of this campaign was a television series, Target: Delinquency (1963), which aired on KUHT and the city's three commercial stations on Sunday afternoons and evenings between February and May 1963. The intention of the series, outlined in an episode called 'Parents' Responsibility and Delinquency', was to describe the factors that contributed to juvenile delinquency and to gain community support for a three-year plan to curb delinquency.

Although GHAY's media campaign was unorthodox compared to the approaches of other grant recipients, it was keeping with the times and other programmes supported by the Kennedy administration. For example, in autumn of 1962, another priority of the Kennedy administration, physical fitness, had its own public health media campaign in 'The Shape of the Nation'. This show was featured as part of the series produced by the US Army, The Big Picture (1951-1964). The 30-minute episode, which aired on multiple major networks, was hosted by Bob Hope. The concluding sequence was narrated by President Kennedy, who promoted his youth fitness programme and entreated all citizens to "join a great national effort to build a strong and better America through physical effort". ${ }^{40}$

The series developed for GHAY's media campaign format entailed two distinct categories. Nine of the 12 episodes were informational and relied on a combination of filmed conversations between GHAY representatives and experts, panel discussions, and a "press conference". With titles like 'Provocative Reading and Delinquency' and 'Delinquency and Youth Unemployment', these episodes examined various factors that led to delinquency. The style of this programme resembled the approach in Searchlights on Delinquency (1957). ${ }^{41}$ Produced for National Educational Television by WTTW in Chicago, the series featured Cook County Sheriff Dr Joseph D. Lohman's exploration of juvenile delinquency through interviews with experts in psychology and sociology as well as interviews with masked delinquents. In some circles, juvenile delinquency was viewed as a matter primarily for law enforcement. However, this series demonstrated an emerging trend of viewing the challenge of delinquency through the lens of public health, highlighting matters of addiction and mental health. 
The remaining three episodes - 'The Lonely Ones', 'The World of Billy Joe', and 'Wasted Youth' - are best described as docufictions. They portrayed dramatized, sensational versions of real-life cases of delinquency. By late 1962, when the Target: Delinquency series was produced, docudrama was fairly well established as a genre in American television. Hoffer and Nelson in their article "Docudrama on American Television" stated that "it has always been easier and cheaper to present fictional entertainment under the guise of realism than to attempt a meticulously factual recreation". ${ }^{42}$ The style of Target: Delinquency echoed established tropes in popular film and television of the time. Certain influences were apparent, such as The Untouchables (1959-1963, ABC-TV), an action drama that followed the crime-fighting efforts of two prohibition agents against organized crime. Influenced by film noir, episodes featured gruff narration and portrayed fictionalized accounts based on the real-life memoir of the main character, Eliot Ness (co-written by Oscar Fraley).

Another clear antecedent of these films was the teen film genre. Beginning in the 1950s, this emerging genre received increased attention from both large production houses (with films like Warner Bros' Rebel Without a Cause in 1955 and Universal Pictures' The Restless Years in 1958) and low-budget "B" movie houses (with productions such as Hot Rod Girl in 1956 and High School Hellcats in 1958). In Teenagers and Teenpics: Juvenilization of American Movies, Thomas Doherty described the nature of teen film in the 1950s. These relied on "exploiting sensational happenings, their notoriety, and their teenage participants" to sell tickets. He identified some of the "stock elements" of the "dangerous youth" subgenre: teenage hangouts, slang language, and an "unthreatening surrogate authority" to replace out-of-touch parents. ${ }^{43}$ All these elements appeared in the Target: Delinquency series.

Target: Delinquency, like the famous teen dramas of the era, presented stereotypes of the rebel and the outcast as well as relatable themes such as conflict with parents, feelings of alienation, and a desire to fit in. However, the intended audience of teen films was actual teens, whereas the cautionary tales in Target: Delinquency were targeted partly or largely at parents.

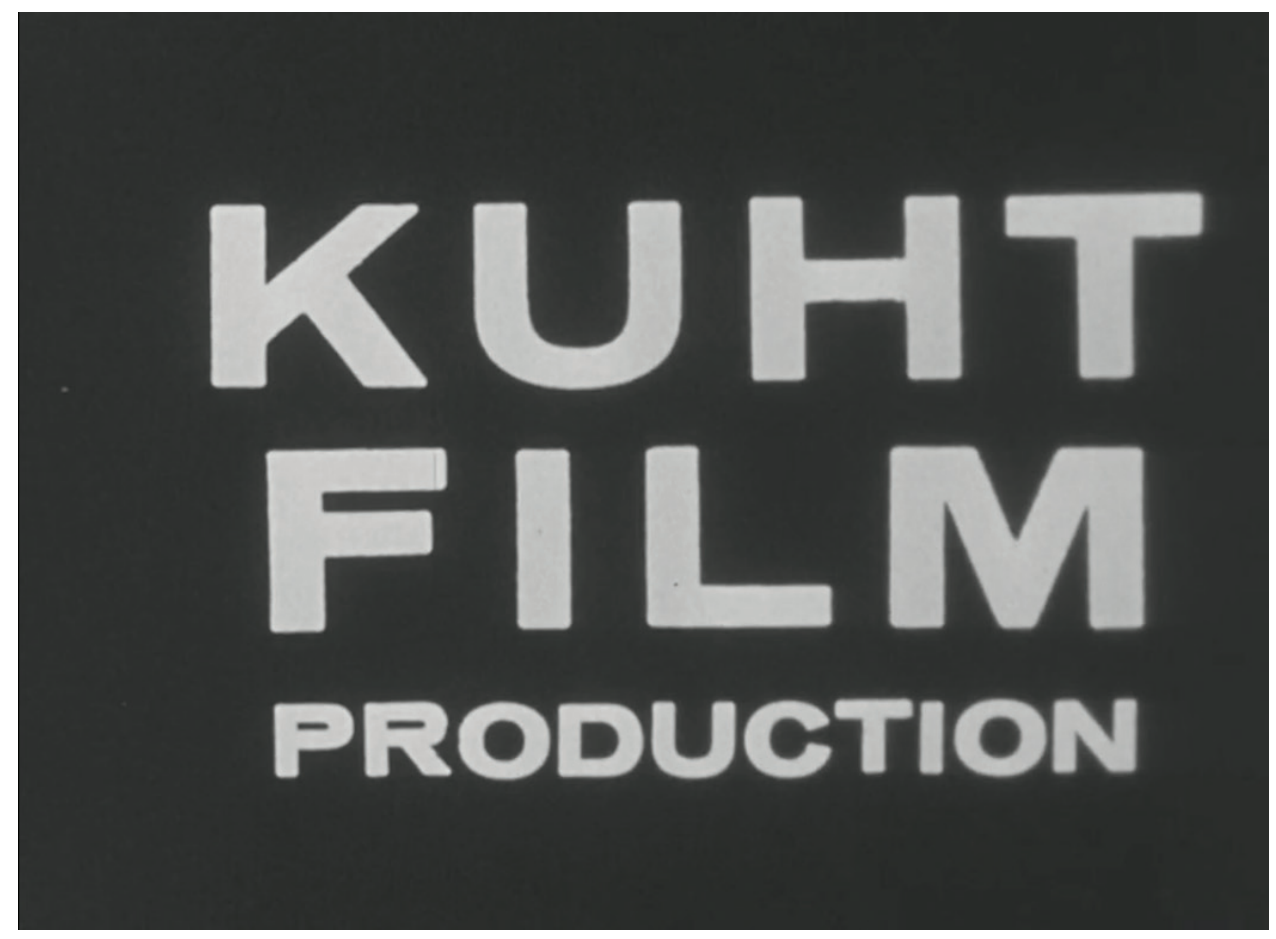

Video 1. Target: Delinquency, 'The Lonely Ones', KUHT, 1963.

The first and most sensational episode of Target: Delinquency, 'The Lonely Ones,' opens with a scene of frenzied action. Discordant music plays as an out-of-control car careens into a tree. Sirens sound, and close-up images of 
bloodied, lifeless youth flash across the screen. The sole survivor of the crash, flung from the car, is seen crawling across the ground, calling out to a fellow passenger. The scene then cuts to a studio shot of Dr Evans. Evans explains to viewers that these episodes are based on "the files" of Houston social services and law enforcement agencies. He comments that if professional ethics allowed the portrayal of actual cases, "they would be even more dramatic".

Paul Brooks (Don LeBlanc), a juvenile probation officer, narrates three stories from his files. The first is that of the drunken joyrider, Jimmy Johnson (Felix Girard). ${ }^{44}$ As in the other stories featured in 'The Lonely Ones', Jimmy's delinquency is firmly attributed to his parents. In Jimmy's case, his mother is introduced as a mother of five, recently "deserted by her fourth husband". After numerous run-ins with the authorities, Jimmy is sentenced by a judge to a year at a correctional facility for youthful offenders. During his absence, his mother leaves the city, and Jimmy is then placed in an idyllic foster home on a ranch far from the temptations of an urban home. Through a brief montage, the audience is shown the clean-cut young man thriving on the ranch under the supportive guidance of a thoughtful foster father.

The narrator then explains that influence on Jimmy by his "city friends" and his "resentment for imagined restrictions" explode into rebellion against the "straight and narrow". This rebellion leads to the theft of a car and the drunken joyride that causes the death of Jimmy's friends. He then faces the criminal charge of "murder by auto".

The next case follows a similar arc: inattentive mother, rebellious youth, and well-meaning social service officers. Susie (Gaye Goodman) is the child of a wealthy but "emotionally bare" and alcoholic mother. Susie engages in "wanton" behaviour because of her insecurity, which leads eventually to narcotic addiction, prostitution, and a prison sentence.

The final instalment of 'The Lonely Ones' relates the tale of Johnny Garcia (Rufus Perez, Nick Perez). Introduced as a "deprived child with no money", eight-year-old Johnny is caught despite running from the authorities "like a small animal". The youngster is assigned juvenile probation officer Mr Brooks. Over the next few years, Brooks develops a relationship with the Garcia family as he seeks to understand the "plight of the Latin". In contrast to the other two story-lines, in this episode, Johnny's problems are not placed squarely on his parents' shortcomings. Johnny is the only minority character featured in the series, and his story contains stereotypes that would be recognizable to a mostly white audience. The narrator describes Johnny's father, Mr Garcia, as a "good" immigrant: he is a caring and hardworking man, a widower who makes a "decent living wage" but struggles to provide for his many children. Although Mr Garcia struggles to understand the "cultural background of the Anglo-American", he readily accepts guidance from local charitable organizations and the probation officer.

The core of Johnny's problem seems to be his small stature and a disproportionate "hot-blooded" temper. Despite years of positive intervention by social services, "the fear and rage of being born underprivileged, of being denied the love of his mother, of being smaller than the rest of the boys" proved to be too much, leading Johnny to fall in with a bad crowd. While drunk, and unable to control himself in the face of jokes about his height, Johnny lashes out and stabs his best friend, killing him.

Unlike many public-health-minded television campaigns, Target: Delinquency offered little in the way of actionable solutions to prevent or mitigate delinquency. In Who Gets A Childhood, juvenile justice historian William S. Bush noted that GHAY's programme "included a significant attempt to shape public opinion on delinquency's causes and solutions, without offering specific plans of its own" ${ }^{45}$ Furthermore, there were major shortcomings in the execution of the series. Perhaps most noteworthy is the lack of diversity depicted in the casts and story-lines. Of all the youths depicted in the docudrama episodes, Johnny was the only non-white character. In 1960, almost $20 \%$ of the city's population was black, ${ }^{46}$ and black youth were strongly over-represented in the county's juvenile justice system. The $\mathrm{UH}$, as KUHT's parent organization and the source of the cast in Target: Delinquency, had only begun to admit black students in the summer of 1962. Bush suggested that the lack of racial diversity in the stories of delinquency might have been a purposeful strategy to pacify local audiences, given that the city had a "long history of racial discrimination, segregation, and hostility to taxpayer-funded social services" ${ }^{47}$ Poverty was also glossed over. Even in 
the story of Johnny, who was initially described as deprived, the audience gradually learned that his father made a liveable income. but had "yielded to [buying] luxuries" for his children and needed only to learn budgeting and home management.

In general, GHAY seemed determined to depict delinquency as a problem that could happen to families of any class, race, or income level. In many cases, concrete real-life issues facing the youth - such as racism, poverty, and the impact of rapid urbanization - were ignored, in favour of a moralizing tone. The cause of delinquent behaviour was viewed as being the parents, be they morally corrupt, distracted, or simply uninformed.

Even at the time of production, there were objections to the handling of the programmes. Two key GHAY contributors who had worked on Target: Delinquency both resigned before 'The Lonely Ones' aired. Mary Ellen Goodman, a respected cultural anthropologist whose research centred on children and their awareness and attitudes towards racial differences; and Jane Brandenberger, a public relations expert, did not provide detailed public accounts for their departure. However, reports at the time indicated that Goodman, at least, objected to the "soft", clean-cut middle-class portrayal of delinquency favoured by Evans. ${ }^{48}$

The impact of Target: Delinquency is difficult to gauge. Following its broadcast, a survey was conducted among members of the public who had viewed at least one episode. The results aligned with the tone of the broadcast, with the vast majority deeming delinquency a "serious" problem and identifying "the family" as its root cause. ${ }^{49}$ However, the findings did not indicate that any behaviours had changed accordingly. Evans, during a 1963 hearing before the US Senate subcommittee on the extension of the Juvenile Delinquency and Youth Offenses Control Act, struggled to justify his decision to invest $\$ 40,000$ on a media campaign. When questioned by a senator if it was "worth it", Evans replied somewhat vaguely: "I think we have found some evidence it was well worth it ... it stirred a great deal of interest". 50

\section{Television and the Prevention of Health-Risk Behaviours}

In January 1964, the Surgeon General of the US, Luther Terry, issued a report called "Smoking and Health". The landmark report stated what had already been evidenced in thousands of articles in the medical literature: smoking causes cancer and can be linked to numerous other health risks, including heart disease and chronic bronchitis. The report made front page news and ultimately became one of the top news stories that year.

Over the next few years, the US Government took significant steps to inform the population about the risks of smoking. Between 1965 and 1971, new laws were passed that required cigarette packaging to include health warnings and broadcasters to air one anti-smoking advertisement or public service announcement for every three paid tobacco advertisements. Eventually, cigarette advertising was banned from television and radio. ${ }^{51}$

Given the mounting societal concerns related to the impact of smoking on health, and Evans experience trying to influence juvenile behaviours in the GHAY project, his interest grew regarding smoking among youth. Writing in a grant application to study this behaviour, Evans noted that "attention has been called to varieties of adolescent behaviour which are highly suggestive in terms of smoking". ${ }^{52}$ At around the same time, Evans conducted a study that examined how health messages could impact behaviours related to oral hygiene. This study examined if messaging framed in a positive-, fear-, or neutral- tone would result in different outcomes. Focused on middle-school-aged children in a school-based dental hygiene programme; television screenings were shown to the study participants. The results, measured by analysing teeth cleanliness of study participants showed the "surprising effectiveness of a positive motivating appeal", ${ }^{53}$ when detailed instructions were provided. ${ }^{54}$ Contrary to widely held belief and in accordance with the findings of other researchers in the 1960s, Evans found that "high-fear arousal alone" or the 
supply of "accurate information regarding the negative health consequences of a particular behaviour alone" would not instigate behavioural change. ${ }^{55}$ The Target: Delinquency films had relied heavily on fear to motivate positive behaviour. (That is, if you are not an attentive parent, your child will become delinquent; if you engage in delinquent behaviour, you will end up in prison or prostitution or will become a murderer). In Evans' adolescent anti-smoking televisionbased health education initiative, he would focus on a new approach to creating positive health outcomes.

Evans applied for a multi-year grant to explore the "social, psychological and behavioural determinants and correlates of smoking". ${ }^{56}$ To provide an understanding of the influences and attitudes of youth smokers and nonsmokers, the researchers would film discussions between "spontaneous groupings of six to ten teenagers each". The participants would not be informed of the purpose of the interviews but would be told only that they would discuss a "provocative" topic. ${ }^{57}$

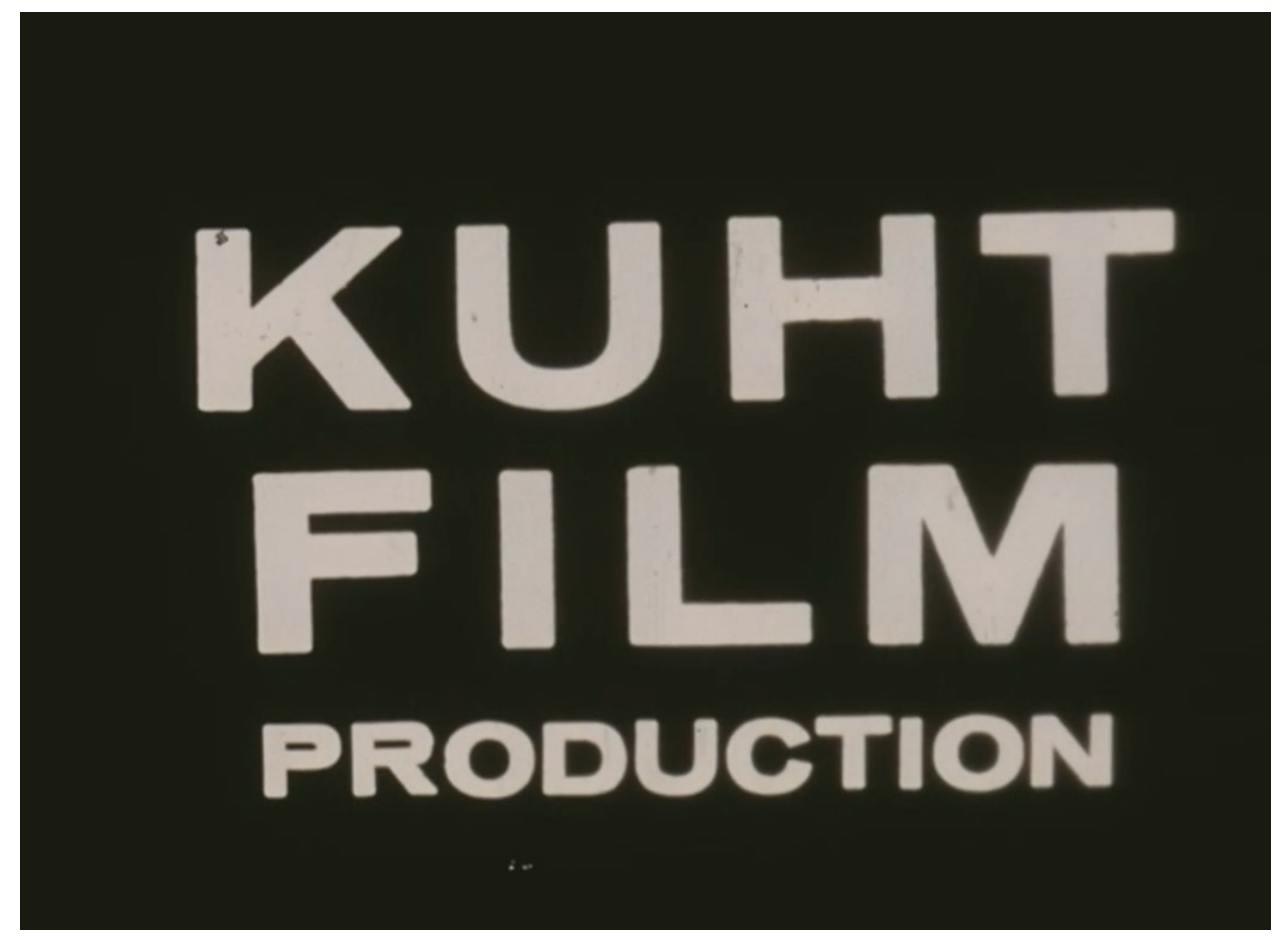

Video 2. Smoke? Why Not?, U.S. Public Health Service, Department of Health, Education, and Welfare, through the Educational Television Stations Program Service,1966.

Smoke? Why Not? (1966) followed Dr Evans as he interviewed a group of teenagers from Aldine High School in the Houston area regarding their smoking habits and attitudes. The interview material was interspersed with experts describing the health risks of smoking. As the group interview progressed, one teen, Rosemary, admitted that if she saw someone smoking it might "lower [my] opinion of them". James, another teen and a self-identified smoker, was quick to react, saying, "if that's going to be the reason someone doesn't like me, they're not a true friend anyways". Others also gave their views, and James eventually admitted that smoking can seem disrespectful depending on the situation.

Evans moved the conversation on to the topic of the health risks associated with cigarette smoking. James said that he did not believe he would develop cancer, but that he was not worried, "because if I'm going to get it, I'm going to get it. That's what I want to do... People don't die of cancer from smoking every day". Again, the other youths were quick to contradict James. This material was followed by Dr Donal M. Billig describing two patients seen that day at his hospital, both of whom had lung cancer and other health complications caused by smoking. 
The basis for Evans' anti-smoking approach was the theory of social inoculation. Introduced by social psychologist William J. McGuire in 1961, this theory posits that just as a vaccine works by exposing the immune system to weakened forms of a virus to build resistance to it, an individual exposed to a "persuasive message that contains weakened arguments against an established attitude" will become resistant to "stronger, future persuasive attacks". 58

The social inoculation model was demonstrated in action in Smoke? Why Not? and was edited for a middle-school audience, aged 11 to 14 . The film drew on the group interviews and focused on the adolescent smoker James, who repeatedly presented a "persuasive message", only to be contradicted by his peers in a well-mannered way. Once confronted with his peers' contradictory views on smoking, James was usually quick to admit the weaknesses in his own argument. The programme also highlighted the influences that might lead a juvenile to smoke. Attention was drawn to James' father's four-pack-a-day habit and enabling tendencies, such as offering to buy James cigarettes. The powerful role that television played in modelling cigarette smoking as a desirable activity was also highlighted. The anti-smoking views presented by the teens were reinforced by the experts who were interviewed and presented medical evidence of the risks of smoking.

In that era, anti-smoking initiatives seemed to have a positive effect on adult smokers. Between 1966 and 1975, rates of smoking among individuals aged 18 and over dropped from $51.9 \%$ to $39.3 \%$ among men and from $33.7 \%$ to $28.9 \%$ among women. ${ }^{59}$ Despite this reduction in adult smokers, in 1976 over a quarter of high school seniors reported they had "smoked daily during the past 30 days", ${ }^{60}$ with smoking levels among teenage boys remaining steady and possibly increasing among teenage girls. Evidence showed that many young people began smoking as they entered middle school, but few formed addictive smoking habits after leaving high school. ${ }^{61}$

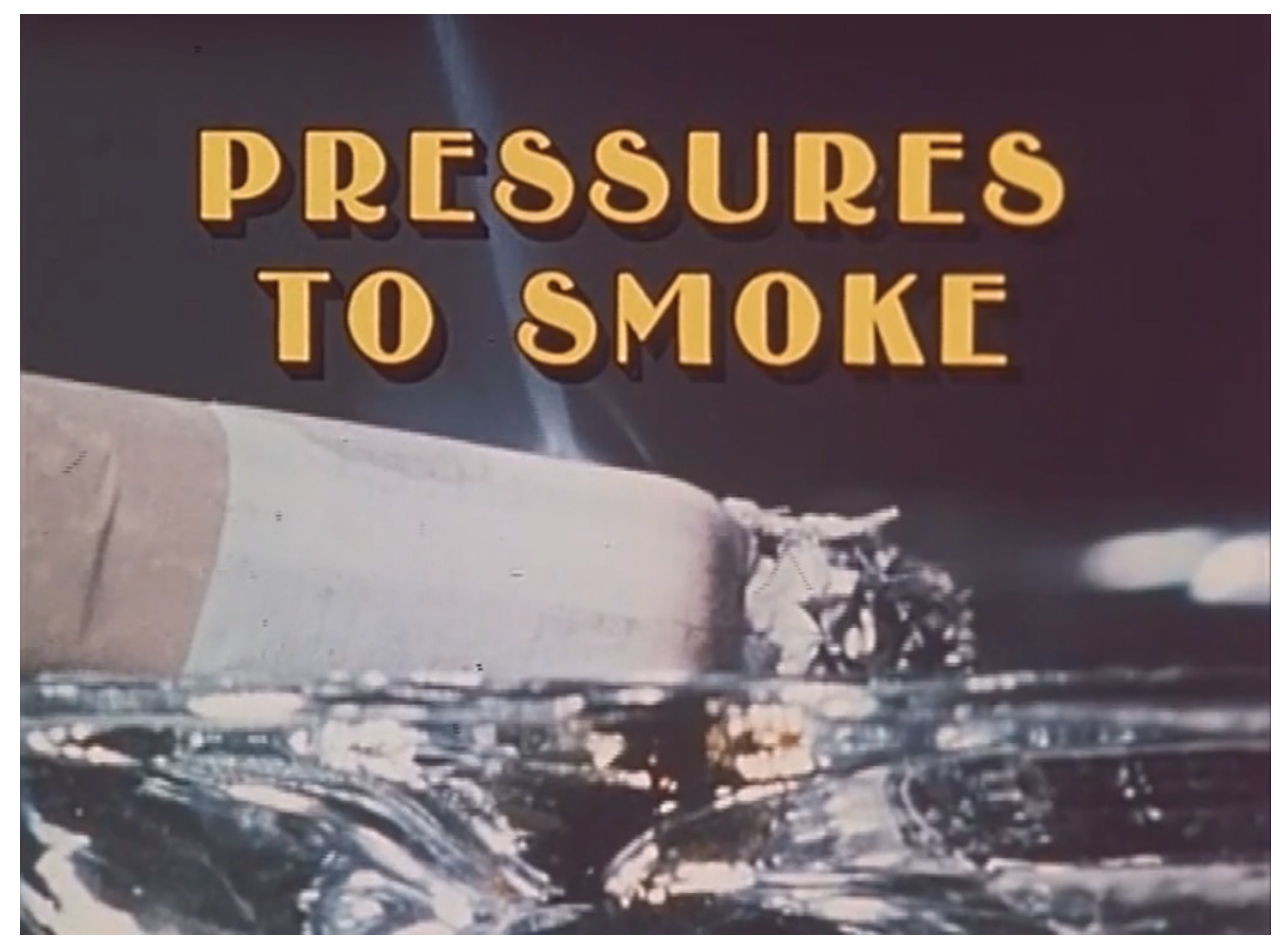

Video 3. Pressures to Smoke, from Social Psychological Deterrents of Smoking in Schools Project, 197X.

In the late 1970s, Evans led a project funded by a grant from the National Heart, Lung, and Blood Institute titled the "Social Psychological Deterrents of Smoking in Schools Project". Two programmes, 'Pressures to Smoke' and 'Resisting Pressures to Smoke', were produced for classroom screening to over 1,300 middle school students in an experimental group. This study was described by social science researcher Laura Corbett as the "first significant application of social psychological principles to a preventative intervention". ${ }^{62}$ Its goal was to 
encourage juveniles not to start smoking by utilizing what Evans called a "social learning-persuasive communications theory". The study utilized a technique based in social inoculation theory, namely peer-modelling of behaviours to resist unhealthy behaviour. This technique was coupled with employing a peer rather than an authority figure as the "teacher" and demonstrating critical analysis of unwanted social influences. The films featured middle-school students as programme hosts and actors, modelling situations the peer audience might find themselves in. Evans and "the Houston group" chose this approach to reduce the "artificiality and adverse effects of using adult authority figures". ${ }^{63}$

Pressures to Smoke fulfilled several functions. It informed the audience about the risks of smoking, with a focus on the immediate health effects of smoking and exposure to second-hand smoke; it reassured them that more people do not smoke than do; it helped to identify the pressures one might face to begin smoking; and it depicted role-playing scenarios with peer-aged actors choosing not to smoke. In Resisting Pressures to Smoke, the teen hosts walked the audience through several strategies to help them avoid smoking, again utilizing role-playing scenes. Specific tactics modelled include stalling for time and being aware of marketing ploys in cigarette advertisements. The film contained frequent refrains encouraging viewers to "think for themselves." The episode ended with a vignette of adolescents saying "no".

In the 1980s, Evans' research on social inoculation was incorporated and overly simplified in First Lady Nancy Reagan's “Just Say No" anti-drug campaign. The "Just Say No" phrase has variously been attributed to University of South Florida advertising student Jordan Zimmerman, ${ }^{64}$ Nancy Reagan, ${ }^{65}$ and the advertising agency Needham Harper \& Steers. ${ }^{66}$ However, its origin in Evans' social inoculation studies, including the Pressures to Smoke films, is evident.

Reagan supported hundreds of speeches and youth events promoting this message. ${ }^{67}$ By the end of President Ronald Reagan's administration in 1988, “over 12,000 'Just Say No' clubs had been formed across the country" ${ }^{68}$ Perhaps the most memorable aspect of the "Just Say No" era was the large-scale advertising initiatives that made the phrase familiar to an entire generation. Using television, the simplistic mantra was spread through the world's popular culture consciousness. There were many celebrity-studded television ads ${ }^{69}$ and sitcom plots based on "Just Say No". ${ }^{70}$ Popular musician Michael Jackson performed a special "Just Say No" version of "Beat It" during the animated children's programme Flintstone Kids (1988) and La Toya Jackson's song "Just Say No". 71

Critics of "Just Say No" and the closely associated Drug Abuse Resistance Education (DARE) programme have pointed out that both initiatives focused on "middle-class youth smoking marijuana". ${ }^{2}$ They did not address those already using drugs and did not examine the devastating crack-cocaine crisis that occurred during the same period. Research has shown that the over-simplified approach of "Just Say No" lacked the benefits of the social inoculation model proposed by Evans - most notably the role-playing elements, which allowed children to practise refusing drugs. ${ }^{73}$ Writing in 1992, Evans et al. expressed concern that the "Just Say No" approach had been "taken out of context and redirected in form as a formula for preventing all substance abuse". They added that "Because of the current pervasiveness of the catchphrase, we emphasize that 'Just Say No' is not enough!"74

\section{Conclusion}

Dr Richard I. Evans was a tireless researcher who worked at UH until his retirement in 2011 at age 89 . During his career, he established the social psychology programme, authored 20 books and over 300 articles, produced numerous television programmes, and obtained millions of dollars in research grants. Following the early promise of the Social Psychological Deterrents of Smoking in Schools Project, Evans conducted many studies on applying aspects of social inoculation and social-learning or persuasive-communications frameworks in preventative 
intervention programmes. These programmes variously focused on smokeless tobacco use, substance abuse, gambling, and unprotected sex.

Dr Evans began his academic and television career in an era that was marked by a widely held conviction that television could both educate the masses and create a healthier population. Working in a fledgling educational television station Evans experimented, examined, and revised his approach to televised health programming. Through archival records, it is possible to trace the trends in public health initiatives, emerging theories of social psychology, and the impact of the oversimplification of these theories into marketing campaigns. The lasting influence of Evan's research, especially his role in televised social psychology initiatives, remains apparent today.

In the decades since Evans' efforts to influence health behaviours through television, there are numerous examples of televised public health efforts undertaken in the US. In Baltimore, the Johns Hopkins School of Hygiene and Public Health collaborated with the local NBC news affiliate WBAL-TV to produce and air health programming segments meant to expand on the storylines presented in the popular medical drama ER. The medical professionals and producers of "Following ER" were allowed details about the weekly plotlines of each ER episode so they could craft relevant segments and help viewers understand steps to take to protect their health. ${ }^{75}$

In 2015, the ABC network drama series How to Get Away with Murder featured an HIV-positive character whose partner takes the daily Pre-Exposure Prophylaxis (PrEP) medication to prevent infection. Airing just three years after the US Food and Drug Administration's approval of the PrEP and the large viewership of the series, it was likely many viewers' first introduction to the preventative treatment. While approaches vary from more traditional educational programming to information embedded in storylines, television continues to be an effective tool for public health practitioners to reach large and diverse audiences.

\section{Notes}

1. Station call letters originated in the 19th century with telegraph operators' need to identify ships without spelling out entire names. Internationally, the practice was formally extended to radio the London International Radiotelegraphic Conference in 1912. The earliest radio and television call numbers in the US were three letters, but by the 1920s as the technology rapidly expanded, moved to four letter identifiers. Save a few exceptions, stations located east of the Mississippi River are assigned call letters that begin with the letter W, those west of the river begin with $\mathrm{K}$. Assignment of call letters was administered the Federal Communications Commission until 1983, which allowed stations to make requests for specific letters. Though not always the case, stations often sought call signs that furthered their brand identity. Thus, when the University of Houston, known locally as $\mathrm{UH}$, launched a radio station it selected KUHF (the F indicating it aired on the FM signal) and a few years later selected KUHT for its sister television station. For a more in-depth discussion of the history of US call letters see: Eric A. Taub, "Call Letter Lore," The New York Times, September 10, 1998, G-11.

2. Edwin Bernard Kurtz, Pioneering in Educational Television (lowa City: State University of lowa, 1959 ), 75 and 105.

3. "Television," The Library of Congress, Moving Image Section--Motion Picture, Broadcasting and Recorded Sound Division, accessed 17 September 2019, https://guides.loc.gov/american-women-moving-image/television

4. Fifth Annual Report of the Federal Communications Commission for Fiscal Year Ended June 30, 1939 (Washington, D.C.: United States Government Printing Office, 1940), 49. www.fcc.gov/reports-research/reports/annual-reports-congress/5thannual-report-congress-1939

5. J. Fred MacDonald, One Nation Under Television: the Rise and Decline of Network TV (New York: Pantheon Books, [1999] 2009), jfredmacdonald.com/onutv/freeze.htm

6. Laurie Ouellette, Viewers Like You: How Public TV Failed the People (New York: Columbia University Press, 2002$), 41$.

7. Grant Price, "Opening A Whole New World: A History Of Broadcasting In lowa, Chapter 7: The Untold Story, W9XK-lowa City," Wartburg College, http://web.archive.org/web/20100702223008/http://www.wartburg.edu/broadcast/Chapter7/Chapter7. html

8. William Hawes, Public Television: America's First Station (Santa Fe: Sunstone Press, 1996), 15.

9. Ouellette, Viewers Like You, 42.

10. Joint Committee on Educational Television, Telford Taylor, Seymour Krieger, and United States. Federal Communications Commission, Comments of Joint Committee On Educational Television: In the Matter of Amendment of Part 3 of the 
Commission's Rules And Regulations Governing Television Broadcast Stations, Before the Federal Communications Commission, Washington 25, D.C., Docket No. 11532, (Washington, D.C.: [G.P.O.?], 1955), 1. https://babel.hathitrust.org/ cgi/pt?id=uiug. $30112028366885 \&$ view=1up\&seq=9

11. "TV Outlets Urged As Education Aids: 7 Groups to Ask F.C.C. Assign Channels in Major Cities for Noncommercial Use," The New York Times, November 21, 1950, 55, www.nytimes.com/1950/11/21/archives/tv-outlets-urged-as-education-aids-7groups-to-ask-fcc-assign.html

12. For an excellent biographical sketch of Frieda Hennock, see Susan L. Brinson, "Frieda Hennock: FCC activist and the campaign for educational television, 1948-1951," Historical Journal of Film, Radio and Television 18, no. 3 (1998).

13. Ralph Steetle, "The Changing Status of Educational Television," The Journal of Educational Sociology 32, no. 9 (1959): 428.

14. Patrick James Nicholson, In time: An anecdotal history of the first fifty years of the University of Houston (Houston: Pacesetter Press, 1977), 155.

15. University of Houston Board of Regents Minutes, 17 April 1951, 2. University of Houston Special Collections, Houston, Texas, United States.

16. Hawes, Public Television, 24.

17. Ibid., 35.

18. Richard I. Evans, Personal values as factors in anti-Semitism (PhD Dissertation, Michigan State University, 1950).

19. The course was accompanied by print booklet: Richard I. Evans, A Telecourse Guide to Introductory Psychology (Houston: University of Houston Press, 1953).

20. Hawes, Public Television, 40.

21. Ibid., 29.

22. Richard I. Evans, H. Burr Roney, and W.J. McAdams, "An evaluation of the effectiveness of instruction and audience reaction to programming on an educational television station," Journal of Applied Psychology 39, no. 4 (1955): 277-279; Richard I. Evans, "An Examination of Students' Attitudes Toward Television As a Medium of Instruction in a Psychology Course," Journal of Applied Psychology 40, no. 1 (1956): 32-4; Richard I. Evans, "Social Psychology on Television: Experimental Programming," American Psychologist 12, no. 8 (1957): 531-2; Richard I. Evans, An Analysis of Some Demographic and Psychological Characteristics of an Educational Television Audience (Ann Arbor, MI: National Educational Television and Radio Center, 1957).

23. Richard I. Evans, "The Planning and Implementation of a Psychology Series on a Non-Commercial Educational Television Station," American Psychologist, 10 (1955): 602-5; Richard I. Evans, "An Exploratory Investigation of the Psychological and Educational Impact of a Filmed Dialogue with Carl Jung," in Conversations with Carl Jung and reactions from Ernest Jones (Princeton, NJ: Van Nostrand, 1964), 159-63; Richard I. Evans, "Contributions to the History of Psychology: X. Filmed Dialogues with Notable Contributors to Psychology," Psychological Reports 25, no. 1 (August 1969): 159-64

24. Richard I. Evans, "A Psychology Professor on the Carson Show," Television Quarterly 6, no. 1 (Winter 1967), 55-9.

25. One example is the It's Your Life series produced by the Chicago Industrial Health Association in 1949 https:// americanarchive.org/catalog?f\%5Bseries_titles $\% 5 \mathrm{D} \% 5 \mathrm{~B} \% 5 \mathrm{D}=\mid \mathrm{t} \% 27 \mathrm{~s}+$ Your+Life\&f[access_types][]=online

26. The final two films in the Red Seal films are available via the MedFilm digital teaching and research platform: The Temple of Moloch (1914) and The Lone Game (1915).

27. Philip P. Jacobs, "Tuberculosis in Motion Pictures," Journal of the Outdoor Life, IX, no. 12 (December 1912): 304. https:// babel. hathitrust.org/cgi/pt?id=uc1.b4332585\&view=1up\&seq=394

28. One Hundred and Forty-Second Annual Report of the Department of Health (Baltimore: Baltimore City Health Department, 1956), 343, http://web.archive.org/web/20100702223008/http://www.wartburg.edu/broadcast/Chapter7/Chapter7.html

29. Bette Kill and Linda Sue King, "Historical Trends in the Use of Television in Health Education," Journal of School Health 53, no. 5 (May 1983): 312

30. Joseph Gordon, "Health Education via Television," Public Health Reports, 68, no. 8 (August 1953): 816.

31. Joseph Gordon, "The 25 th Anniversary of 'Your Family Doctor'," Health Services Reports 89, no. 4 (July-August 1974): 393-4.

32. Esther D. Schulz, "Television Brings Drama to Clinic Patients," The American Journal of Nursing 62, no. 8, (August 1962): 98-9.

33. Anne B. Wagner and Mary Ellen Patno, "The Use of a Series of TV Programs to Educate Parents in Child Care," Public Health Reports, 71, no. 8 (August 1956): 780.

34. "Table 107. Percent of high school dropouts (status dropouts) among persons 16 to 24 years old, by sex and race/ethnicity: 1960-2003," Digest of Education Statistics, 2005, https://nces.ed.gov/programs/digest/d04/tables/dt04_107.asp

35. David L. Hackett, Template letter inviting Special Advisers to the Committee on Juvenile Delinquency and Youth Crimes (undated), Folder Committee on Juvenile Delinquency and Youth Crime, 18 April 1962 - 17 October 1963, Papers of John F. Kennedy, Presidential Papers, President's Office Files, John F. Kennedy Presidential Library and Museum, Boston, Massachutesets, United States. Digital Identifier: JFKPOF-093-007-p0005, https://www.jfklibrary.org/asset-viewer/ archives/JFKPOF/093/JFKPOF-093-007

36. Shahid M.Shahidullah, Crime Policy in America (Lanham, MD: University Press of America, 2008), 10. 
37. Richard A. Cloward and Lloyd E. Ohlin, Delinquency and Opportunity: A Theory of Delinquent Gangs (Glencoe, IL: Free Press, 1960), 175.

38. Shaina Abraha, Steve Bede, Jessica Jerney, Misty Schomber, "Mobilization For Youth: A Revolution in Youth Work," (Graduate student paper, University of Minnesota, 15 November 2007), 9, https://pdfs.semanticscholar.org/ef7f/ e40ac51f2cac89d5a963a8498a84549b1b4f.pdf

39. “Juvenile Delinquency Act," Congressional Quarterly Almanac 17, (1961): 204-6, http://library.cqpress.com/cqalmanac/ cqal61-1372911

40. United States Army, "Shape of the Nation," The Big Picture, 1962, https://archive.org/details/gov.archives.arc.2569812

41. Searchlights on Delinquency, (Chicago, IL: WTTW, 1957), https://americanarchive.org/ catalog?q=Searchlights+on+Delinquency\&utf8=\%E2\%9C\%93\&f[access_types][]=online

42. Tom W. Hoffer and Richard Alan Nelson, "Docudrama on American Television," Journal of the University Film Association 30, no. 2, (Spring 1978): 23.

43. Thomas Doherty, Teenagers and Teenpics (Philadelphia, PA: Temple University Press: 2002), 7 and 89.

44. This story was perhaps inspired by the true story of Charles Ronald Young, aged 17, and Bill Young, aged 16 . The 7 January 1963 edition of the Houston Chronicle newspaper featured the front page headline "Fleeing Stolen Auto Kills Three Women" and shows photos of mangled cars as well as the two bandaged youths. Houston Chronicle clipping, 7 January 1963, Profesor Tom Battin Collection, Box 6, Folder 10: Research Materials for "Action for Youth" project University of Houston Special Collections, Houston, Texas, United States.

45. William S. Bush, Who Gets a Childhood? Race and Juvenile Justice in Twentieth-Century Texas (Athens, GA: University of Georgia Press, 2010), 140.

46. Stephen L. Klineberg, Houston's Economic and Demographic Transformations: Findings from the Expanded 2002 Survey of Houston's Ethnic Communities (Houston: Rice University, 2002), 10, https://www.datahouston.org/khas/HAS2002 reportPDF.pdf

47. Bush, Who Gets a Childhood, 144 .

48. William S. Bush, Representing the Juvenile Delinquent: Reform, Social Science, and Teenage Troubles in Postwar Texas (PhD Dissertation, University of Texas, 2004), 139-40.

49. Bush, Who Gets a Childhood, 146.

50. United States. Congress. Senate. Committee on Labor and Public Welfare. Subcommittee on Employment, M. (1963). Extension of the Juvenile Delinquency Act: hearings before the United States Senate Committee on Labor and Public Welfare, Subcommittee on Employment and Manpower, Eighty-Eighth Congress, first session, on Aug. 8, 9, 13, 15, 16, 1963. Washington: U.S. G.P.O.

51. This ad, created by renowned sound and media designer Tony Schwartz, is considered to be the first anti-smoking advertisement on television. "Tony Schwartz Collection," The Library of Congress Recorded Sound Research Collection, accessed 15 April 2020, www.loc.gov/rr/record/schwartzcollection.html

52. "U.S. Department of Health, Education, and Welfare Application for Research Grant," College of Arts and Sciences Records, Folder 22: Research Grants -. Psychology (Evans) 1961-1964, University of Houston Libraries Special Collections, Houston, Texas, United States.

53. Participant's teeth were rated on a five-point scale, from "very clean" to "very dirty". Evans, et. al. developed a technique of photographing the teeth of participants who had eaten a "disclosing wafer' which, when chewed, stains the plaque on the teeth red and thereby reveals the amount of this plaque." The study technique is detailed in: Richard I. Evans, et al. "Fear arousal, persuasion, and actual versus implied behavioral change: New perspective utilizing a real-life dental hygiene program," Journal of Personality and Social Psychology 16, no. 2 (1970): 223.

54. Richard I. Evans, Richard M. Rozelle, Thomas M. Lasater, Theodore M. Dembroski, Bem P. Allen, "Fear arousal, persuasion, and actual versus implied behavioral change: New perspective utilizing a real-life dental hygiene program," Journal of Personality and Social Psychology 16, no. 2 (1970): 220-7.

55. Richard I. Evans and J. Greg Getz, "Social Inoculation," in Encyclopedia of Primary Prevention and Health Promotion, eds. Thomas P. Gullotta and Martin Bloom (Boston, MA: Springer, 2003): 1029.

56. "U.S. Department of Health, Education, and Welfare Application for Research Grant," 1.

57. Ibid, 8

58. Josh Compton, Ben Jackson, and James A. Dimmock, "Persuading Others to Avoid Persuasion: Inoculation Theory and Resistant Health Attitudes," Frontiers in Psychology, 7 (February 2016).

59. John M. Pinney, ed., "Smoking and Health: A Report of the Surgeon General: Appendix: Cigarette Smoking in the United States, 1950-1978," (United States: Public Health Service, 1979), A-10 https://profiles.nlm.nih.gov/spotlight/nn/catalog/ nIm:nImuid-101584932X675-doc

60. Fred C. Pampel and Jade Aguilar, "Changes in Youth Smoking, 1976-2002: A Time-Series Analysis," Youth \& Society 39, no. 4 (2008): 453.

61. Richard Evans, Richard M. Rozelle, Scott E. Maxwell, Bettye E. Raines, Charles A. Dill, Tanya J. Guthrie, Allen H. Henderson, and Peter C. Hill, "Social Modeling Films to Deter Smoking in Adolescents: Results of a Three-Year Field Investigation," Journal of Applied Psychology, 66, No. 1 (1981): 399 
62. Laura Corbett, "Promoting Healthy Behaviour: Evidence from Psychology," Future public health: Burdens, challenges and opportunities (Palgrave Macmillan, 2014): 105.

63. Ibid., 402.

64. Tracy Byrnes, "3 Branding Tips From the Man Who Helped Create Nancy Reagan's 'Just Say No' Campaign," Fortune, March 8, 2016, https://fortune.com/2016/03/08/3-branding-tips-nancy-reagan/

65. "Her Causes," The Ronald Reagan Presidential Foundation \& Institute, www.reaganfoundation.org/ronald-reagan/nancyreagan/her-causes/

66. Sam Roberts, "Robert Cox, Man Behind the 'Just Say No' Antidrug Campaign, Dies at 78," The New York TImes, June 22, 2016, https://www.nytimes.com/2016/06/23/business/media/robert-cox-man-behind-the-just-say-no-antidrugcampaign-dies-at-78.html

67. "Her Causes," The Ronald Reagan Presidential Foundation \& Institute.

68. Ibid.

69. "DEA Say no to drugs ads 1980s compilation" (3 June 2018) featuring Brooke Shields, David Hasselhoff, Mr. T, and others, accessed 16 April 2019, https://www.youtube.com/watch?v=3phzVSysURQ

70. Several popular television shows featured "Just Say No" storylines, including an episode of Diff'rent Strokes titled "The Reporter," Season 5, Episode 22 (1983), in which Nancy Reagan guest-starred, http://www.criticalcommons.org/Members/ philipje/clips/diff2019rent-strokes-201cthe-reporter-201d-nancy/view; Punky Brewster, “Just Say No," 2: 8, (1985); numerous other shows followed the familiar storyline, though not all with overt "Just Say No" branding: https://www.ifc. com/2016/05/just-say-no-sitcom-episodes.

71. La Toya Jackson, "Just Say No," 1988, https://www.youtube.com/watch?v=Bj9IK60RJEc

72. Stephen T. Schroth, Jason A. Helfer, Jordan K. Lanfair, "Just Say No," in Encyclopedia of Drug Policy, eds. Mark A. R. Kleiman and James E. Hawdon (Thousand Oaks, CA: SAGE Publications, Inc., 2011).

73. Scott O. Lilienfeld and Hal Arkowitz, "Why 'Just Say No' Doesn't Work," Scientific American 25, no. 1 (January 2014 ), 70-1.

74. Richard I. Evans, Bettye E. Raines, and Greg Gatz, "Applying the Social Inoculation Model To a Smokeless Tobacco Use Prevention Program With Little Leaguers" in Smokeless Tobacco Or Health: An International Perspective US Dept. of Health and Human Services (Bethesda, MD: National Cancer Institute, Sept. 1992), 260-1.

75. Randolph Fillmore, "SPH Reaches Out to Educate 'Following ER,'” The Gazette, January 27, 1997, https://pages.jh.edu/ gazette/janmar97/jan2197/follow.html

\section{Biography}

Emily Vinson is Audiovisual Archivist and curator of the KUHT and KUHF Collections at the University of Houston Libraries Special Collections. Prior to UH, Emily worked as an archivist at Rice University's Baker Institute for Public Policy; a project archivist preserving unique audio holdings at New York Public Radio; and a fellow in Preservation Administration at New York Public Library. Vinson is active in the Association of Moving Image Archivists, and past president of Archivists of the Houston Area. She holds an MSc in Information Studies with a Certificate of Advanced Studies in Preservation Administration from the University of Texas, Austin. 